\title{
Design, Synthesis, In Vivo Anti-inflammatory, Analgesic Activities and Molecular Docking of Some Novel Pyrazolone Derivatives
}

\author{
Ahmad Farouk Eweas ${ }^{1,3 *}$, Ahmed OH El-Nezhawy,3, Rehab Fawzy Abdel-Rahman ${ }^{4}$ and Ayman R Baiuomy ${ }^{4,5}$ \\ ${ }^{1}$ Medicinal Chemistry Department, National Research Center, Dokki, Cairo, Egypt \\ ${ }^{2}$ Department of Chemistry of Natural and Microbial Products, National Research Center, Dokki, Cairo, Egypt \\ ${ }^{3}$ Pharmaceutical Chemistry Department, College of Pharmacy, Taif University, Taif, KSA \\ ${ }^{4}$ Pharmacology Department, National Research Center, Dokki, Cairo, Egypt \\ ${ }^{5}$ Faculty of Medicine and Medical Sciences, Taif University, KSA
}

\begin{abstract}
A novel series of 1,5-dimethyl-2-phenyl-1,2-dihydro-3H-pyrazol-3-one derivatives were synthesized. The synthesis started with the important building block 3, which was prepared via coupling of from 2-(bis (methylthio) methylene) malononitrile 1 with 4-amino-1,5-dimethyl-2-phenyl-1,2-dihydro-3H-pyrazol-3-one 2 . The 5-aminopyrazole derivatives 4-8 were prepared from the cyclocondensation of 3 with the appropriate sulfonohydrazides and pyridine4-carbohydrazide respectively. Cyclocondensation of 1 or 9 with pyridine-4-carbohydrazide and 4-methylbenzene sulfonohydrazide corresponding pyrazole derivatives 10,11, 12 and 13. Condensation 2 and 1-isothiocyanato-4methylbenzene 14 yielded 15 which was refluxed with malonic acid to yielded1-(1,5-dimethyl-3-oxo-2-phenyl-2,3dihydro-1H-pyrazol-4-yl)-2-thioxo-3-(2methylphenyl) dihydropyrimidine-4,6 $(1 H, 5 H)$-dione (16). All tested compounds showed analgesic and anti-inflammatory activities in comparison to the reference standard drugs tramadol, acetyl salicylic acid and indomethacin. Maximum protection against the thermal stimulus was observed at 90 min following the administration of the compound (5) (105.8\%), which was statistically significant comparable to the reference drug tramadol $(148.7 \%)$. Compounds $(5,6,11$ and 13$)$ revealed their maximal analgesic effect after $60 \mathrm{~min}(68.5 \%, 77.5 \%$, $84.6 \%$ and $89.7 \%$, respectively), then their effect started to decrease. In addition, derivatives 10, 12 and 16 showed anti-inflammatory activity after 4 hours, which was greater than that of the reference drug indomethacin and reached the maximum effect at the $2^{\text {nd }} \mathrm{h}$. Additionally, a molecular docking study was performed against the COX enzyme using the Molsfot ICM 3.8 software.
\end{abstract}

Keywords: Pyrazole; Anti-inflammatory; Analgesic; Indomethacin; Molecular docking

\section{Introduction}

The anti-inflammatory properties of Nonsteroidal antiinflammatory drugs (NSAIDs) have been attributed to their ability to inhibit the enzyme cyclooxygenase (COX) enzymes, which catalyzes the formation of arachidonic acid (AA) to prostaglandins $\mathrm{H}_{2}\left(\mathrm{PGH}_{2}\right)$ [1-4]. Many of (NSAIDs) have a wide clinical use in the treatment of acute or chronic inflammation [5,6]. There are two isoforms of cyclooxygenase (COX); COX-1 and COX-2 [7]. These isoforms are poorly distinguishable by most of the classical NSAIDs. They actually inhibit COX-1 extensively; COX-1 has housekeeping functions, including low-level production of gastro protective PGs, besides COX2, leading to gastrointestinal injury, suppression of Thromboxane A2 (TXA2) formation and platelet aggregation. The combination of these interactions is probably the reason for gastrointestinal bleeding as the most serious complication of these drugs [8]. To prevent or decrease these side effects, a current strategy consists of designing selective COX-2 inhibitors with an improved gastric safety profile. The improved safety profile of COX-2 inhibitors may allow the use of these new agents for long-term prophylactic use in certain chronic diseases. This has led intense efforts in search for potent and selective COX-2 inhibitors, which could provide anti-inflammatory drugs with fewer risks. Several classes of compounds having selective COX-2 inhibitory activity have been reported in the literature such as SC-558 and celecoxib. Pyrazole, pyrazoline, and pyrazolone ring systems found in many non-steroidal anti-inflammatory drugs have been used for clinical application as NSAIDS like celecoxib [9] antipyrine, phenylbutazone, ramifenazone and famprofazone. Antipyrine is the first pyrazoline derivative used in the management of pain, inflammation and fever (Figure 1) [1013]. Pyrazoles are considered among the most important class of heterocyclic compounds having a broad spectrum of application in the field of medicinal chemistry [14]. Pyrazole derivatives were found to exhibit anti-inflammatory [15-17], analgesic [18], antitumor [19,20], antiviral [21,22], anticonvulsant [23] and antimicrobial activities $[22,24]$. The importance of pyrazole derivatives as antimicrobial agents attracted attention after the discovery of the natural pyrazole C-glycoside pyrazofurin which demonstrated a broad spectrum of antimicrobial activities [25]. Appreciation with the well-documented anti-inflammatory and analgesic properties associated with these heterocyclic cores and as part of our continuing work in the area of drug discovery including anti-inflammatory and analgesic compounds [26-28], herein we report the synthesis of new pyrazolone derivatives in combination with pyrazole and dihydropyrimidinone scaffold, in addition to heteroaryl and aryl pyrazole derivatives. The analgesic and anti-inflammatory activities of all novel compounds were investigated utilizing the acetic acid-induced writhing test and the carrageenaninduced hind paw edema test, respectively. Furthermore, a molecular docking study was carried out for the most potent anti-inflammatory new compounds against COX-1 and COX-2 crystal structures in an attempt to understand their binding mode to both enzymes in comparison to the reference drug indomethacin.

*Corresponding author: Ahmad Farouk Eweas, Medicinal Chemistry Department National Research Center, Dokki, Cairo, Egypt, Tel: 00966559058923; E-mail: eweas1@gmail.com

Received September 03, 2015; Accepted October 20, 2015; Published October 15,2015

Citation: Eweas AF, El-Nezhawy AOH, Abdel-Rahman RF, Baiuomy AR (2015) Design, Synthesis, In Vivo Anti-inflammatory, Analgesic Activities and Molecular Docking of Some Novel Pyrazolone Derivatives. Med chem 5: 458-466. doi:10.4172/2161-0444.1000301

Copyright: ( $) 2015$ Eweas AF, et al. This is an open-access article distributed under the terms of the Creative Commons Attribution License, which permits unrestricted use, distribution, and reproduction in any medium, provided the original author and source are credited. 


\section{Materials and Methods}

\section{Chemistry}

All chemicals were purchased from common commercial suppliers and used without further purification. All reactions were carried out under argon with dry solvents. Also all reactions were monitored by TLC carried out on Merck silica gel-coated plastic sheets (60 F254) by using UV light as visualizing agent. Thin layer chromatography (TLC) was performed on silica gel 60 F254 plastic plates (E.Merck, layer thickness $0.2 \mathrm{~mm}$ ). Detection was achieved by treatment either with a solution of $20 \mathrm{~g}$ of ammonium molybdate and $0.4 \mathrm{~g}$ of cerium (IV) sulfate in $400 \mathrm{ml}$ of $10 \% \mathrm{H}_{2} \mathrm{SO}_{4}$ or with $15 \% \mathrm{H}_{2} \mathrm{SO}_{4}$, and heating at $150^{\circ} \mathrm{C}$. Melting points were determined on a Gallenkamp melting point apparatus and were uncorrected. IR spectra $(\mathrm{KBr})$ were recorded on a Perkin-Elmer 1650 spectrophotometer, NRC. ${ }^{1} \mathrm{H}$ and ${ }^{13} \mathrm{C}$ NMR were determined on a Varian Mercury $(300 \mathrm{MHz})$ spectrometer (Varian, $\mathrm{UK}$ ) and the chemical shifts were expressed in $\delta$ ppm relative to TMS as an internal reference, Faculty of science, Cairo University. Mass spectra were recorded on Thermo Finnigan LCQ Advantage spectrometer in ESI mode, I Spray Voltage $4.8 \mathrm{kV}$. Microanalyses were performed at the Micro analytical Center of Cairo University.

2-(((1,5-dimethyl-3-oxo-2-phenyl-2,3-dihydro-1H-pyrazol-4-yl) amino)(methylthio) methylene)malononitrile [31] (3): A mixture of 2-(bis(methylthio)methylene)malononitrile $1(10 \mathrm{mmol})$ and 4 -amino1,5-dimethyl-2-phenyl-1,2-dihydro-3 $H$-pyrazol-3-one $2(10 \mathrm{mmol})$ in ethanol $(20 \mathrm{ml})$ was heated under reflux for $12 \mathrm{~h}$ (under TLC control). The reaction mixture was cooled, poured into ice-water and the solid formed was filtered off and crystallized from methanol to give product of type 2-(((1,5-dimethyl-3-oxo-2-phenyl-2,3-dihydro-1H-pyrazol-4yl)amino) (methylthio) methylene)malononitrile 3.

\section{General method for preparation of 4-8}

A mixture of compound (3) (10 mmol) and benzenesulfonohydrazide, 4-methylbenzene-sulfonohydrazide, 4-bromobenzenesulfonohydrazide, 2-thiourcil-5-sulfonohydrazide or pyridine-4-carbohydrazide respectively $(10 \mathrm{mmol})$ in toluene $(30 \mathrm{ml})$ was refluxed for 8-12 h. The solid obtained after cooling was filtered off, dried on suction, and crystallized from ethanol to give products of type $4-8$.

5-amino-3-((1,5-dimethyl-3-oxo-2-phenyl-2,3-dihydro1H-pyrazol-4-yl)amino)-1-(phenylsulfonyl)-1 H-pyrazole-4carbonitrile (4): Yield $75 \%$, m.p. $295-297^{\circ} \mathrm{C}$, IR $\left(\mathrm{KBr}, \mathrm{cm}^{-1}\right): 3547,3425$ $\left(\mathrm{NH}_{2}, \mathrm{NH}\right), 3030-3019$ (C-H aromatic), $2218(\mathrm{CN}), 1627(\mathrm{C}=\mathrm{N}), 1322$,

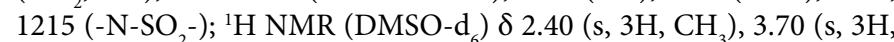
$\left.\mathrm{N}-\mathrm{CH}_{3}\right), 6.90-8.20(\mathrm{~m}, 10 \mathrm{H}$, aromatic), 9.10, 10.40 and $11.70(\mathrm{~s}, 3 \mathrm{H}$, $\mathrm{NH}_{2}, \mathrm{NH}$ exchangeable with $\left.\mathrm{D}_{2} \mathrm{O}\right)$; MS: $(\mathrm{m} / \mathrm{z}) \mathrm{M}^{+}$at $\mathrm{m} / \mathrm{z}$ (449) (7\%); Anal. Calcd. for $\mathrm{C}_{21} \mathrm{H}_{19} \mathrm{~N}_{7} \mathrm{O}_{3} \mathrm{~S}$ (449.49): C, 56.11; H, 4.26; N, 21.81; S, 7.13. Found: C, 26.74; H, 4.16; N, 21.74; S, 7.20.

5-amino-3-((1,5-dimethyl-3-oxo-2-phenyl-2,3-dihydro-1Hpyrazol-4-yl)amino)-1-tosyl-1H-pyrazole-4-carbonitrile (5): Yield 71\%, m.p. 265-267 ${ }^{\circ} \mathrm{C}$; IR (KBr, cm $\left.{ }^{-1}\right): 3547,3425\left(\mathrm{NH}_{2}, \mathrm{NH}\right), 3030,3019$ (C-H aromatic), $2208(\mathrm{CN}), 1630(\mathrm{C}=\mathrm{N}), 1322,1215\left(-\mathrm{N}-\mathrm{SO}_{2}-\right) ;{ }^{1} \mathrm{H}$ NMR (DMSO-d $) \delta 2.20\left(\mathrm{~s}, 3 \mathrm{H}, \mathrm{CH}_{3}\right), 2.33\left(\mathrm{~s}, 3 \mathrm{H}, \mathrm{CH}_{3}\right), 3.70(\mathrm{~s}, 3 \mathrm{H}$, $\mathrm{N}-\mathrm{CH}_{3}$ ), 6.90-8.20 (m, 9H, aromatic), 9.10, 10.20, 11.50 (s, 3H, $\mathrm{NH}_{2}$, $\mathrm{NH}$ exchangeable with $\mathrm{D}_{2} \mathrm{O}$ ); MS (EI) $\mathrm{m} / \mathrm{z}(\%): 463.5$ (10, M+); Anal. Calcd. for $\mathrm{C}_{22} \mathrm{H}_{21} \mathrm{~N}_{7} \mathrm{O}_{3} \mathrm{~S}$ (463.51): C, 57.01; H, 4.57; N 21.15; S, 6.92. Found: C, 57.09; H, 4.73; N, 21.43; S, 6.80 .

5-amino-1-((4-bromophenyl)sulfonyl)-3-((1,5-dimethyl-3oxo-2-phenyl-2,3-dihydro-1H-pyrazol-4-yl)amino)-1H-pyrazole4-carbonitrile (6): Yield 79\%; m.p. $252-254^{\circ} \mathrm{C}$; IR $\left(\mathrm{KBr}, \mathrm{cm}^{-1}\right)$ : 3447 , $3345\left(\mathrm{NH}_{2}, \mathrm{NH}\right), 3030,3025$ (C-H aromatic), $2214(\mathrm{CN}), 1621(\mathrm{C}=\mathrm{N})$, 1322, $1215\left(-\mathrm{N}-\mathrm{SO}_{2}-\right)$; ${ }^{1} \mathrm{H}$ NMR (DMSO-d $)$ $\delta 2.30\left(\mathrm{~s}, 3 \mathrm{H}, \mathrm{CH}_{3}\right), 3.74$ (s, $\left.3 \mathrm{H}, \mathrm{N}-\mathrm{CH}_{3}\right), 6.42-8.30$ (m, 9H, aromatic), 9.10,10.01, $11.42(\mathrm{~s}, 3 \mathrm{H}$, $\mathrm{NH}_{2}, \mathrm{NH}$ exchangeable with $\mathrm{D}_{2} \mathrm{O}$ ); MS (EI) m/z (\%): 528.3 (9, M+); Anal. Calcd. for $\mathrm{C}_{21} \mathrm{H}_{18} \mathrm{BrN}_{7} \mathrm{O}_{3} \mathrm{~S}$ (528.38): C, 47.74; $\mathrm{H}, 3.43$; $\mathrm{Br}, 15.12$; N, 18.56; S. 6.07. Found: C, 47.64; H, 3.30; Br, 15.02; N, 18.50; S. 6.14.

5-amino-3-((1,5-dimethyl-3-oxo-2-phenyl-2,3-dihydro$1 \mathrm{H}$ - pyrazol-4 - yl) a mino - 1 - ( ( 4 - oxo-2 - thioxo-1, 2, 3, 4tetrahydropyrimidin-5-yl)sulfonyl)-1H-pyrazole-4-carbonitrile (7): Yield 75\%; m.p. $>300^{\circ} \mathrm{C}$; IR $\left(\mathrm{KBr}, \mathrm{cm}^{-1}\right): 3427,3315$ and $3225\left(\mathrm{NH}_{2}, \mathrm{NH}\right)$, 3030, 3019 (C-H aromatic), 2212(CN), $1622(\mathrm{C}=\mathrm{N}), 1322,1215(-\mathrm{N}-$ $\left.\mathrm{SO}_{2}-\right) ;{ }^{1} \mathrm{H}$ NMR (DMSO-d $) \delta 2.41\left(\mathrm{~s}, 3 \mathrm{H}, \mathrm{CH}_{3}\right), 3.72\left(\mathrm{~s}, 3 \mathrm{H}, \mathrm{N}-\mathrm{CH}_{3}\right)$, 6.90-8.21 (m, 5H, aromatic, $\mathrm{C}=\mathrm{CH}$ of thiouracil), 9.41,10.10,11.22, 11.40 and $12.41\left(\mathrm{~s}, 5 \mathrm{H}, \mathrm{NH}_{2}, 3 \mathrm{NH}\right.$ exchangeable with $\left.\mathrm{D}_{2} \mathrm{O}\right)$; $\mathrm{MS}(\mathrm{EI})$<smiles>Cc1ccc(-c2cc(C(F)(F)F)nn2-c2ccc(S(N)(=O)=O)cc2)cc1</smiles>

Celecoxib<smiles>CC(C)NC1C(=O)N(c2ccccc2)N(C)C1C</smiles>

Remifenazone<smiles>Cc1cc(=O)n(-c2ccccc2)n1C</smiles>

Antipyrine<smiles>CCCCC1C(=O)N(c2ccccc2)N(c2ccccc2)C1=O</smiles>

Phen ylbutazone<smiles>CC(C)c1c(C(C)CN(C)C(C)Cc2ccccc2)n(C)c(=O)n1-c1ccccc1</smiles>

Famprofazone

Figure 1: Some reported pyrazole-containing anti-inflammatory agents. 
$\mathrm{m} / \mathrm{z}(\%): 499.5(16, \mathrm{M}+)$; Anal. Calcd. for $\mathrm{C}_{19} \mathrm{H}_{17} \mathrm{~N}_{9} \mathrm{O}_{4} \mathrm{~S}_{2}(499.53): \mathrm{C}$, 45.68; H, 3.43; N, 25.24; S. 12.84. Found: C, 45.60; H, 3.31; N, 25.20; S. 12.89 .

5-amino-3-((1,5-dimethyl-3-oxo-2-phenyl-2,3-dihydro- $1 H$ pyrazol-4-yl)amino)-1-(pyridin-4-ylcarbonyl)- $1 \mathrm{H}$-pyrazole-4carbonitrile (8): Yield $80 \%$; m.p. $275-277^{\circ} \mathrm{C}$; IR $\left(\mathrm{KBr}, \mathrm{cm}^{-1}\right): 3447,3365$ and $3286\left(\mathrm{NH}_{2}, \mathrm{NH}\right), 3030-3019(\mathrm{C}-\mathrm{H}$ aromatic), $2218(\mathrm{CN}), 1672$, $1665(2 \mathrm{CO}), 1620(\mathrm{C}=\mathrm{N}) ;{ }^{1} \mathrm{H}$ NMR (DMSO-d $) \delta 2.52\left(\mathrm{~s}, 3 \mathrm{H}, \mathrm{C}-\mathrm{CH}_{3}\right)$, $3.85\left(\mathrm{~s}, 3 \mathrm{H}, \mathrm{N}-\mathrm{CH}_{3}\right), 6.30-8.41(\mathrm{~m}, 9 \mathrm{H}$, aromatic), 9.12,10.00, 11.40 (s, $3 \mathrm{H}, \mathrm{NH}_{2}$, NH exchangeable with $\left.\mathrm{D}_{2} \mathrm{O}\right) ; \mathrm{MS}(\mathrm{EI}) \mathrm{m} / \mathrm{z}(\%): 414(11$, $\mathrm{M}+$ ); Anal. Calcd. for $\mathrm{C}_{21} \mathrm{H}_{18} \mathrm{~N}_{8} \mathrm{O}_{2}$ (414.42): C, 60.86; H, 4.38; N, 27.04 . Found: $\mathrm{C}, 60.70 ; \mathrm{H}, 4.32 ; \mathrm{N}, 27.14$.

\section{General method for preparation of 10 and 12}

An equimolar amounts of 2-(bis(methylthio)methylene) propanedinitrile $1(10 \mathrm{mmol})$ and pyridine-4-carbohydrazide or 4-methylbenzenesulfonohydrazide $(10 \mathrm{mmol})$ and $2-4$ drops of triethylamine in $(25 \mathrm{ml})$ methanol was heated for $8 \mathrm{~h}$. The reaction mixture was cooled, poured onto ice-water and the solid formed was collected by filtration, dried under suction and crystallized from ethanol absolute to give (10 or 12).

5-amino-3-(methylsulfanyl)-1-(pyridin-4-ylcarbonyl)- $\mathbf{H}$ pyrazole-4-carbonitrile (10): Yield 75\%; m.p. $>300^{\circ} \mathrm{C}$; IR $\left(\mathrm{KBr}, \mathrm{cm}^{-1}\right)$ : 3427 and $3359\left(\mathrm{NH}_{2}\right), 3058$ and $3026(\mathrm{C}-\mathrm{H}$ aromatic), $2218(\mathrm{CN}), 1676$ (CO); ${ }^{1} \mathrm{H}$ NMR (DMSO-d $) \delta 2.72$ (s, 3H, S-CH $), 4.10-4.22$ (bs, $2 \mathrm{H}$, $\mathrm{NH}_{2}$, exchangeable with $\left.\mathrm{D}_{2} \mathrm{O}\right), 7.90(\mathrm{~d}, j=4.3,2 \mathrm{H}$, pyridyl), $8.70(\mathrm{~d}$, $j=4.2,2 \mathrm{H}$, pyridyl); MS (EI) m/z (\%): 259 (18, M+); Anal. Calcd. for $\mathrm{C}_{11} \mathrm{H}_{9} \mathrm{~N}_{5} \mathrm{OS}$ (259.29): C, 50.95; H, 3.50; N, 27.01; S, 12.37. Found: C, $50.80 ; \mathrm{H}, 3.58 ; \mathrm{N}, 26.91 ; \mathrm{S}, 12.22$.

5-amino-3 - (methylsulfanyl) - 1 - tosyl- $1 \mathrm{H}$-pyrazole-4carbonitrile(12): Yield 79\%; m.p. $>300^{\circ} \mathrm{C}$; IR $\left(\mathrm{KBr}, \mathrm{cm}^{-1}\right): 3420$ and $3368\left(\mathrm{NH}_{2}\right), 3030$ and $3016(\mathrm{C}-\mathrm{H}$ aromatic), $2212(\mathrm{CN}), 1320,1225$ $\left(-\mathrm{N}-\mathrm{SO}_{2}-\right) ;{ }^{1} \mathrm{H}$ NMR (DMSO-d $) \delta 2.30\left(\mathrm{~s}, 3 \mathrm{H}, \mathrm{CH}_{3}\right), 2.79(\mathrm{~s}, 3 \mathrm{H}$, S- $\mathrm{CH}_{3}$ ), 4.30-4.45 (bs, $2 \mathrm{H}, \mathrm{NH}_{2}$, exchangeable with $\mathrm{D}_{2} \mathrm{O}$ ), 7.50, 7.77 (m, 6H, aromatic); MS (EI) m/z (\%): 308 (26, M+); Anal. Calcd. for $\mathrm{C}_{12} \mathrm{H}_{12} \mathrm{~N}_{4} \mathrm{O}_{2} \mathrm{~S}_{2}$ (308.38): C, 46.74; H, 3.92; N, 18.17; S, 20.80. Found: C, $46.65 ; \mathrm{H}, 3.79 ; \mathrm{N}, 18.10 ; \mathrm{S}, 20.89$.

\section{General method for preparation of 11 and 13}

An equimolecular amounts of (ethoxy-methylidene) propanedinitrile $9(10 \mathrm{mmol})$ and pyridine-4-carbohydrazide or 4-methylbenzenesulfonohydrazide $(10 \mathrm{mmol})$ and $4-6$ drops of triethylamine in $(25 \mathrm{ml})$ methanol was heated for $8 \mathrm{hrs}$. The reaction mixture was cooled, poured onto ice-water and the solid formed was collected by filtration, dried under suction and crystallized from ethanol absolute to give (11 or 13).

5-amino-1-(pyridin-4-ylcarbonyl)- $\mathbf{H}$-pyrazole-4-carbonitrile (11): Yield 75\%; m.p. 295-297 $\mathrm{C}$; IR $\left(\mathrm{KBr}, \mathrm{cm}^{-1}\right): 3569-3338\left(\mathrm{NH}_{2}\right), 3066-$ 3040 (C-H aromatic), 2220 (CN), 1682 (CO ); ${ }^{1} \mathrm{H}$ NMR (DMSO-d $) \delta$ $7.68(\mathrm{~d}, j=5.1,2 \mathrm{H}$, pyridyl), $8.15(\mathrm{~s}, 1 \mathrm{H}, \mathrm{N}=\mathrm{CH}$ of pyrazoline), 8.60 (d, $j=5.0,2 \mathrm{H}$, pyridyl); MS (EI) m/z (\%): 213 (22, M+); Anal. Calcd. for $\mathrm{C}_{10} \mathrm{H}_{7} \mathrm{~N}_{5} \mathrm{O}$ (213.20): C, 56.34; H, 3.31; N, 32.85. Found: 56.25; H, 3.20; $\mathrm{N}, 32.80$

5-amino-1- [ (4-methylphenyl) sulfonyl]- $1 \mathrm{H}$-pyrazole-4carbonitrile (13): Yield 75\%; m.p. $265-267^{\circ} \mathrm{C}$; IR $\left(\mathrm{KBr}, \mathrm{cm}^{-1}\right): 3419$ and $3330\left(\mathrm{NH}_{2}\right), 3096$ and $3026(\mathrm{C}-\mathrm{H}$ aromatic), $2224(\mathrm{CN}), 1618$ $(\mathrm{C}=\mathrm{N}), 1325,1229\left(-\mathrm{N}_{-} \mathrm{SO}_{2}-\right) ;{ }^{1} \mathrm{H}$ NMR $\left(\mathrm{DMSO}-\mathrm{d}_{6}\right) \delta 2.34\left(\mathrm{~s}, 3 \mathrm{H}, \mathrm{CH}_{3}\right)$, 6.30-6.46 (bs, $2 \mathrm{H}, \mathrm{NH}_{2}$, exchangeable with $\left.\mathrm{D}_{2} \mathrm{O}\right), 7.50,7.77(\mathrm{~m}, 4 \mathrm{H}$, aromatic), 8.13 (s, $1 \mathrm{H}, \mathrm{N}=\mathrm{CH}$ of pyrazoline); MS (EI) m/z (\%): 262 (20,
$\mathrm{M}+$ ); Anal. Calcd. for $\mathrm{C}_{11} \mathrm{H}_{10} \mathrm{~N}_{4} \mathrm{O}_{2} \mathrm{~S}$ (262.29): C, 50.37; H, 3.84; N, 21.36; S, 12.23. Found: C, 50.33; H, 3.71; N, 21.30; S, 12.16 .

1-(1,5-dimethyl-3-oxo-2-phenyl-2,3-dihydro- $1 H$-pyrazol-4-yl)2-thioxo-3-(2-methylphenyl)dihydropyrimidine-4,6(1H,5H)-dione (16): A mixture of 4-amino-1,5-dimethyl-2-phenyl-1,2-dihydro- $3 \mathrm{H}$ pyrazol-3-one $2(0.01 \mathrm{~mol})$ and tolylisothiocyanate $14(0.01 \mathrm{~mol})$ in $(30 \mathrm{ml})$ dry toluene was refluxed for $5 \mathrm{~h}$. The product obtained after cooling was filtered off, dried and crystallized from acetic acid to afford compound 1-(1,5-dimethyl-3-oxo-2-phenyl-2,3-dihydro- $1 \mathrm{H}$ pyrazol-4-yl)-3-(2-methylphenyl)thiourea 15 . A mixture of compound (15) $(0.01 \mathrm{~mol})$ and malonic acid $(0.01 \mathrm{~mol})$ was heated with $(30 \mathrm{ml})$ acetylchloride on water bath for $10 \mathrm{~h}$, then cooled and poured drop wise on ice /water, the produced precipitate was filtered off, dried under vacuum and crystallized from methanol to give compound (16).

Yield 70\%; m.p. $>300^{\circ} \mathrm{C}$; $\mathrm{IR}\left(\mathrm{KBr}, \mathrm{cm}^{-1}\right): 3058,3026$ (C-H aromatic), $1715,1685,1639$ (2CO, CO of pyrazolone); ${ }^{1} \mathrm{H}$ NMR (DMSO-d $\left.\mathrm{d}_{6}\right) \delta$ $2.40\left(\mathrm{~s}, 3 \mathrm{H}, \mathrm{C}-\mathrm{CH}_{3}\right), 2.60\left(\mathrm{~s}, 3 \mathrm{H}, \mathrm{C}-\mathrm{CH}_{3}\right), 3.80\left(\mathrm{~s}, 3 \mathrm{H}, \mathrm{N}-\mathrm{CH}_{3}\right), 3.90$ (s, $\left.1 \mathrm{H}, \mathrm{CH}_{2}\right), 6.80-8.20$ (9H,m, aromatic); MS (EI) m/z (\%): $420(17, \mathrm{M}+$ ); Anal. Calcd. for $\mathrm{C}_{22} \mathrm{H}_{20} \mathrm{~N}_{4} \mathrm{O}_{3} \mathrm{~S}$ (420.48): C, 62.84; H, 4.79; N, 13.32; S, 7.63. Found: C, $62.71 ; \mathrm{H}, 4.71 ; \mathrm{N}, 13.20 ; \mathrm{S}, 7.53$.

\section{Pharmacological Assay}

\section{Materials and methods}

Animals: Albino mice and rats used in this experiment were obtained from the Animal House Colony at the National Research Centre (NRC), Egypt. Albino mice of both sexes (25-30 g b. wt) and Wistar rats of both sexes (150-200 g b. wt) were utilized. All animals were housed under standard conditions and were reserved in polyethylene cages under standard conditions (temperature $25 \pm 3$, and relative humidity $60 \pm 10 \%$ ) of natural $12 \mathrm{~h}$ light and dark cycle with free access to food and water. Animals were allowed to adapt to the laboratory environment for one week before experimentation. Mice and rats will be used only once in this study. All animal procedures were performed after approval from the Ethics Committee of The National Research Centre- Egypt and in accordance with the recommendations of the proper care and use of laboratory animals.

Analgesic activity: Analgesic activity of the selected Compounds was carried out in mature Albino mice (25-30 g body weight) by using two different models.

a. Central analgesic activity (Hot plate test): The central analgesic activity of the selected Compounds was tested in mice as described by Turner [29] using hot-plate apparatus. Seventy two mice were divided into 12 groups of 6 animals each. Mice of the $1^{\text {st }}$ (normal control) and $2^{\text {nd }}$ (reference one) groups were treated orally with the vehicle $(5 \mathrm{ml} / \mathrm{kg}$ ) and tramadol $(40 \mathrm{mg} / \mathrm{kg})$, respectively. Animals of the $3^{\text {rd }}$ till the $12^{\text {th }}$ groups were orally given the selected Compounds at doses of $(20 \mathrm{mg} / \mathrm{kg}$, p.o.). One h post-medication, mice were placed individually on a hot plate maintained at $53 \pm 0.5^{\circ} \mathrm{C}$. The time taken by the animals to lick the fore or hind paw or jump out of the place was taken as the reaction time for the thermal stimulus. The reaction time was measured at 0,30 , 60 and 90 min after treatment. The cutoff time for the response to the thermal stimulus was set at $60 \mathrm{Sec}$. to avoid tissue damage to the mouse paws. All drugs were dissolved in DMSO (20 mg/kg, orally), except tramadol (was dissolved in DMSO, $40 \mathrm{mg} / \mathrm{kg}$, orally).

b. Peripheral analgesic activity (Writhing test): The peripheral analgesic activity of the selected Compounds was determined in mice as described by Collier [30]. Seventy two mice were divided into 12 groups of 6 animals each. Mice of the $1^{\text {st }}$ (normal control) and $2^{\text {nd }}$ (reference one) groups were treated orally with the vehicle $(5 \mathrm{ml} / \mathrm{kg}$ ) 
and acetyl salicylic acid $(150 \mathrm{mg} / \mathrm{kg})$, respectively. Animals of the $3^{\text {rd }}$ till the $12^{\text {th }}$ groups were orally given the selected Compounds at doses of $(20 \mathrm{mg} / \mathrm{kg}$, p.o.). After $30 \mathrm{~min}$ of medication, writhing was induced by an intraperitoneal injection of acetic acid ( $0.7 \%$ aqueous solution) in a dose of $10 \mathrm{ml} / \mathrm{kg}$ b.wt. All drugs were dissolved in DMSO $(20 \mathrm{mg} /$ $\mathrm{kg}$, orally), except acetyl salicylic acid (was dissolved in DW, $150 \mathrm{mg} /$ $\mathrm{kg}$, orally). Mice were then placed in transparent boxes and the number of writhes per animal was counted for 20 min after acetic acid injection and expressed as the percentage of protection using the following ratio:

Protection (\%)+[Control mean - Treated mean/ Control mean] $\times 100$.

Anti-inflammatory activity: Carrageenan-induced mouse paw edema model: The anti-inflammatory testing was performed according to the method of Winter [31] in Wistar rats. Paw edema was induced in rats by subcutaneous (s.c.) injection of $0.1 \mathrm{ml}$ of $1 \%(\mathrm{w} / \mathrm{v})$ carrageenan in distilled water in the sub-plantar region of their left hind paws. A group of six rats was left without any treatment, but orally given a respective volume of the solvent (DMSO), and was kept as control. The selected Compounds were administered at doses of $(20 \mathrm{mg} / \mathrm{kg}$, p.o.). Indomethacin $(20 \mathrm{mg} / \mathrm{kg}$, p.o.) was used as a reference drug. The paw volumes of the rats were measured using plethysmometer, before and after injection of $1 \%$ carragennan at different time intervals $(1,2,3$ and $4 \mathrm{~h}$ ). Edema and inhibition rates of each group were calculated at the above-mentioned time intervals as follows:

Edema $(\%)=[\mathrm{Vt}-\mathrm{Vo} / \mathrm{Vo}] \times 100$

Inhibition $(\%)=[\mathrm{Ec}-\mathrm{Et} / \mathrm{Ec}] \times 100$

Where, Vo is the volume before carrageenin injection [8], Vt is the volume at $\mathrm{t}$ hour after carrageenin injection [8], Ec is the edema rate of the control group, and Et is the edema rate of the treated group. All drugs were dissolved in DMSO $(20 \mathrm{mg} / \mathrm{kg}$, orally), except indomethacin (was dissolved in DW).

Statistical analysis: Statistical analysis of results, was done using analytical software named SPSS statistics 17.0, Release (Aug. 23, 2008), Chicago, USA.

\section{Molecular docking}

All docking studies were performed using "Internal Coordinate Mechanics (Molsoft ICM 3.8)". A set of three compounds 10, 12 and 16 designed to inhibit cyclooxygenases was compiled and 3D structures were constructed using Chembio3D ultra 13.0 software [Molecular Modelling and Analysis; Cambridge Soft Corporation, USA (2013)]. They were then energetically minimized by using MOPAC (semi empirical quantum mechanics), Job Type with 100 iterations and minimum RMS gradient of 0.01 , and saved as MDL Mol File ( $\left.{ }^{*} \cdot \mathrm{mol}\right)$. The X-ray crystallographic structures of COX-1 (PDB: 3KK6) in complex with celecoxib and COX-2 complexed with a non-selective inhibitor, Indomethacin (PDB: 4COX) were obtained from the Protein
Data Bank http://www.rcsb.org.

\section{Results and Discussion}

\section{Chemistry}

The crucial building block 2-(((1,5-Dimethyl-3-oxo-2-phenyl2,3-dihydro-1H-pyrazol-4-yl)amino) (methylthio) methylene) malononitrile 3 was prepared from 2-(bis(methylthio) methylene) malononitrile 1 and 4-amino-1,5-dimethyl-2-phenyl-1,2-dihydro- $3 \mathrm{H}$ pyrazol-3-one 2 in ethanol under reflux according to the procedure described in the literature [32] (Scheme 1).

The 5-aminopyrazole derivatives 4-8 were prepared from the cyclocondensation of 2-(((1,5-Dimethyl-3-oxo-2-phenyl-2,3-dihydro1H-pyrazol-4-yl)amino) (methylthio) methylene)malononitrile 3 with benzenesulfonohydrazide, 4-methylbenzene-sulfono hydrazide, 4-bromobenzenesulfonohydrazide, 2-thiourcil-5-sulfonohydrazide or pyridine-4-carbohydrazide respectively in toluene and refluxed for 8-12h (Scheme 2). The chemical structures of 4-8 were established based on their spectral data and elemental analysis. The IR spectra of 4-8 showed bands between $3550 \mathrm{~cm}^{-1}$ and $3400 \mathrm{~cm}^{-1} 1$ for the $\mathrm{NH}$ and $\mathrm{NH}_{2}$ groups respectively, $2200 \mathrm{~cm}^{-1}$ for $\mathrm{CN}$ and $1215 \mathrm{~cm}^{-1}$ for $\left(-\mathrm{N}-\mathrm{SO}_{2}\right)$. ${ }^{1} \mathrm{H}$ NMR spectra showed singlet signals with $\delta$ values between $9.12 \mathrm{ppm}$ and 11.40 for $\mathrm{NH}_{2}$ and $\mathrm{NH}$ exchangeable with $\mathrm{D}_{2} \mathrm{O}$. The structures of 4-8 were supported by their mass spectrometry (MS) results, which showed molecular ions corresponding to the molecular formulas of compounds 4-8.

Cyclocondensation of 2-(bis(methylthio)methylene) propanedinitrile 1 with pyridine-4-carbohydrazide and 4-methylbenzenesulfonohydrazide in refluxing methanol containing a catalytic amount of triethylamine, yielded the corresponding pyrazole derivatives 10, 11. In addition Cyclocondensation of ethoxymethylidene) propan- dinitrile 9 with pyridine-4-carbohydrazide or 4-methylbenzene sulfono hydrazide in refluxing methanol containing a catalytic amount of triethylamine yielded the corresponding pyrazole derivatives 12, 13 as demonstrated in Scheme 3. The structures of new pyrazole derivatives 10-13 were established based on their spectral data and elemental analysis.

Condensation of 4-amino-1,5-dimethyl-2-phenyl-1,2-dihydro$3 \mathrm{H}$-pyrazol-3-one 2 and 1-isothiocyanato-4-methylbenzene 14 in toluene under reflux yielded 1-(1,5-dimethyl-3-oxo-2-phenyl-2,3dihydro-1H-pyrazol-4-yl)-3-(2-methylphenyl)thiourea 15 which was refluxed with malonic acid for $10 \mathrm{~h}$ to afford 1-(1,5-dimethyl-3-oxo2-phenyl-2,3-dihydro-1H-pyrazol-4-yl)-2-thioxo-3-(2-methylphenyl) dihydropyrimidine-4,6(1H,5H)-dione 16 (Scheme 4$)$. The proposed structure of (16) was established based on spectral data and elemental analysis and spectral data. The IR spectra of (16) showed bands 1715, 1685 and $1639 \mathrm{~cm}^{-1}, 2 \mathrm{CO}$ groups of dihydropyrimidindione ring and one $\mathrm{CO}$ group of pyrazolone ring. ${ }^{1} \mathrm{H}$ NMR spectra showed singlet<smiles>CC(C)=C(C#N)C#N</smiles>

1<smiles>Cc1c(N)c(=O)n(-c2ccccc2)n1C</smiles>

2<smiles>CSC(Nc1c(C)n(C)n(-c2ccccc2)c1=O)=C(C#N)C#N</smiles>

3

Scheme 1: Reagents and conditions: (a) ethanol, reflux, $12 \mathrm{~h}$. 


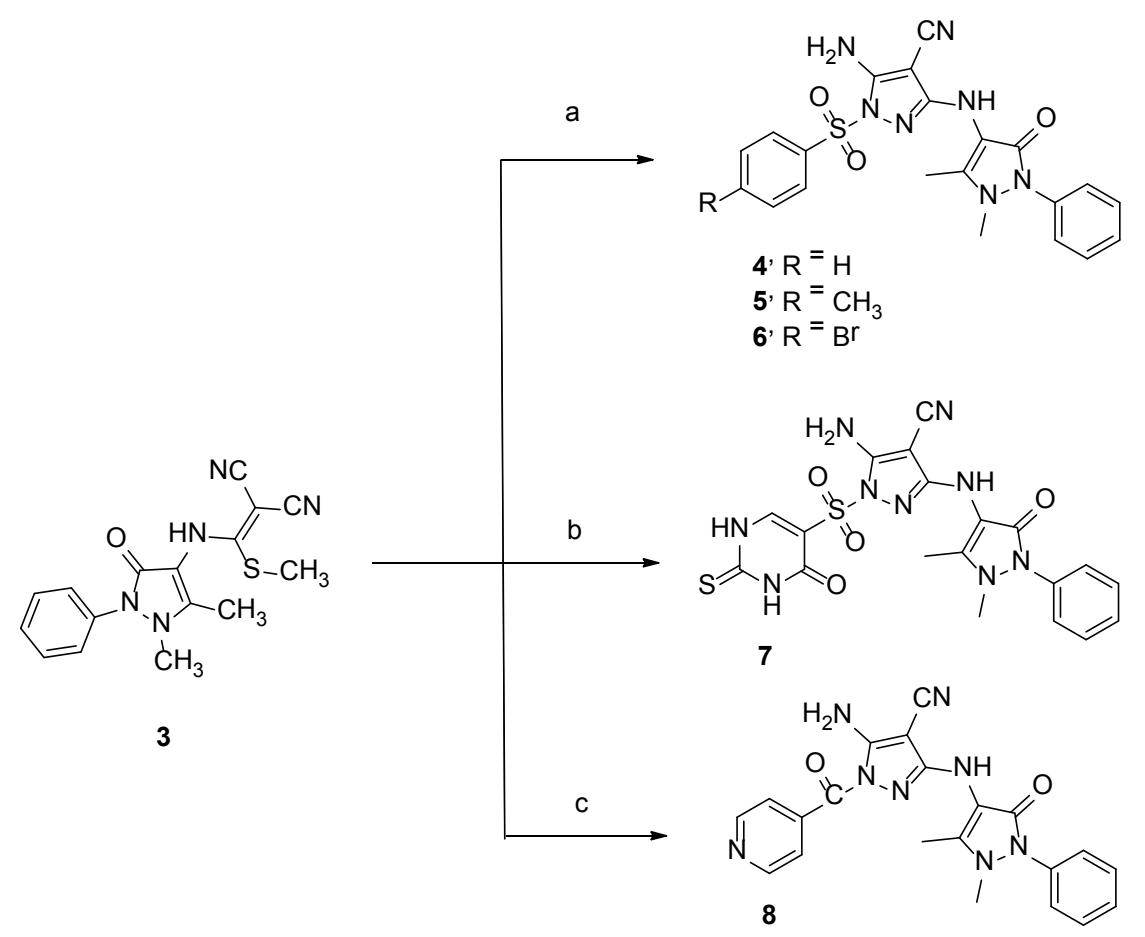

Scheme 2: Reagents and conditions: (a) benzenesulfonohydrazide, toluene, reflux, $8 \mathrm{~h}, 4$ : 4-methylbenzenesulfonohydrazide, toluene, reflux, 10h, 5: 4-bromobenzenesulfonohydrazide, toluene, reflux, 12h, 6; (b) 2-thiourcil-5-sulfonohydrazide toluene, reflux, 10h, 7; (c) pyridine-4-carbohydrazide, toluene, reflux, 12h 8 .

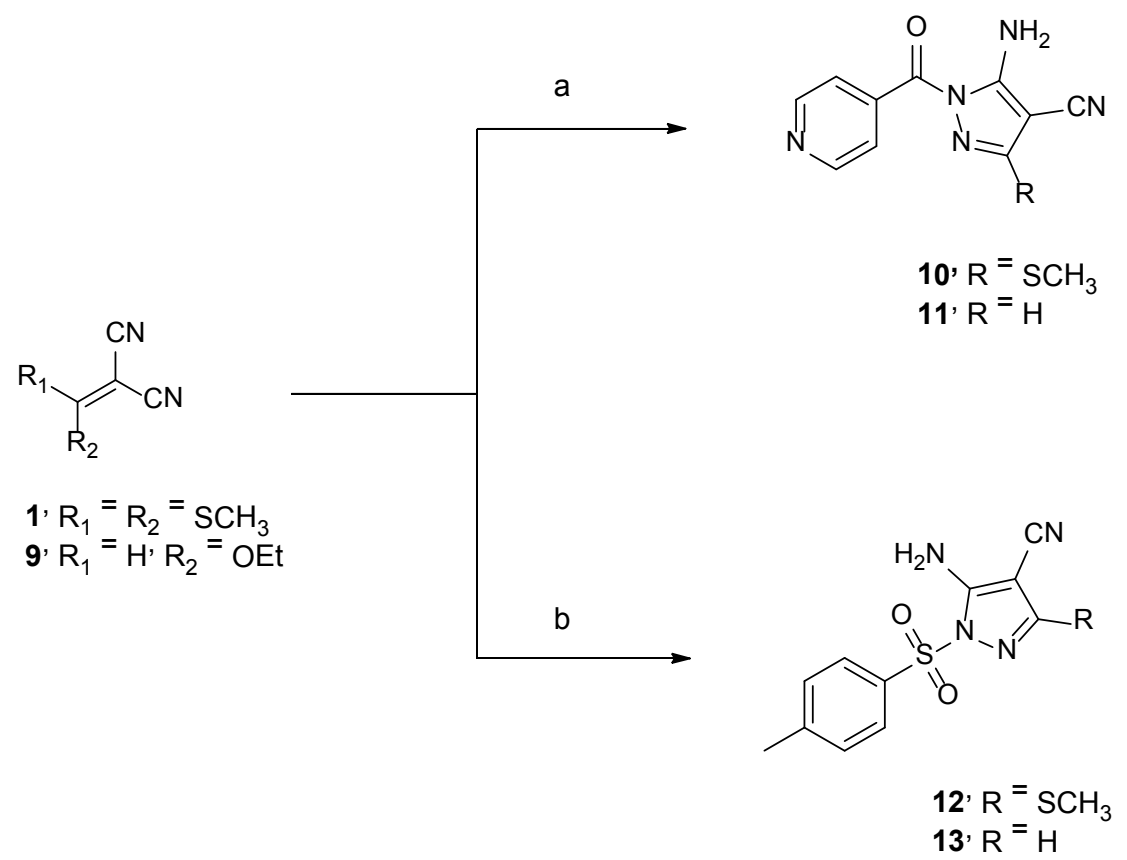

Scheme 3: Reagents and conditions: (a) pyridine-4-carbohydrazide, triethylamine, methanol, reflux, 8h 10 and 11; (b) 4-methylbenzenesulfono hydrazide, triethylamine, methanol, reflux, 8h 12 and 13.

signals with $\delta$ value 3.90 for methylene of dihydropyrimidine ring. Mass spectra showed molecular ion peak at $\mathrm{m} / \mathrm{z} 420$.

\section{Pharmacology}

Analgesic activity: a. Central analgesic activity (Hot plate test): All tested compounds as well as the reference drug tramadol significantly prolonged the reaction time against the thermal stimulus as compared to the control one after 30,60 and 90 min of administration (Table 1). Maximum protection against the thermal stimulus was observed at 90 min following the administration of the compound (5) (105.8\%), which was statistically significant comparable to the reference drug tramadol (148.7\%). As shown in Table 1, compounds (5, 6, 11 and 13) revealed 


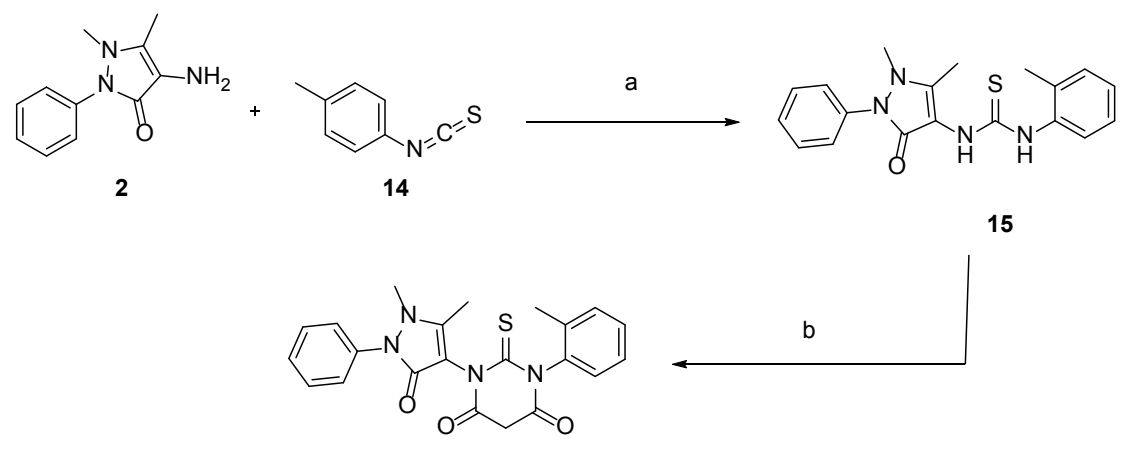

16

Scheme 4: Reagents and conditions: (a) toluene, reflux, 5 h 15 (b) malonic acid, acetyl chloride, reflux, 10 h 16.

\begin{tabular}{|c|c|c|c|c|c|c|c|}
\hline \multirow[t]{2}{*}{ Group } & \multirow{2}{*}{$\begin{array}{l}0 \text { min Reaction } \\
\text { Time [25] }\end{array}$} & \multicolumn{2}{|c|}{$30 \mathrm{~min}$} & \multicolumn{2}{|c|}{$60 \mathrm{~min}$} & \multicolumn{2}{|c|}{$90 \mathrm{~min}$} \\
\hline & & Reaction Time [25] & Protection (\%) & Reaction Time [25] & Protection (\%) & Reaction Time [25] & Protection (\%) \\
\hline Control & $14.0 \pm 1.02$ & $15.2 \pm 1.30 \neq$ & 0 & $15.6 \pm 0.71 \neq$ & 0 & $15.4 \pm 0.48 \neq$ & 0 \\
\hline 4 & $15.0 \pm 1.28$ & $23.5 \pm 1.43^{*} \neq$ & 54.6 & $24.9 \pm 1.61^{*} \neq$ & 59.6 & $27.8 \pm 1.26^{*} \neq$ & 80.5 \\
\hline 5 & $15.8 \pm 1.14$ & $25.5 \pm 0.44^{*}$ & 67.7 & $26.3 \pm 0.38^{*}$ & 68.5 & $31.7 \pm 0.68^{*} \neq$ & 105.8 \\
\hline 6 & $14.6 \pm 1.18$ & $24.0 \pm 0.70^{*} \neq$ & 57.8 & $27.7 \pm 1.22^{*}$ & 77.5 & $28.6 \pm 0.80^{*} \neq$ & 83.7 \\
\hline 7 & $13.3 \pm 0.40$ & $17.5 \pm 0.40 \neq$ & 15.1 & $20.9 \pm 0.82 \ddagger$ & 33.9 & $21.1 \pm 1.05 \ddagger$ & 37 \\
\hline 8 & $15.7 \pm 0.78$ & $21.0 \pm 1.97^{*} \neq$ & 38.1 & $23.3 \pm 1.74^{*} \neq$ & 49.3 & $26.1 \pm 1.59^{*} \neq$ & 69.4 \\
\hline 10 & $14.8 \pm 1.22$ & $21.9 \pm 1.76^{*} \neq$ & 44 & $23.6 \pm 1.85^{\star} \neq$ & 51.2 & $26.0 \pm 1.51^{*} \neq$ & 68.8 \\
\hline 11 & $16.0 \pm 0.61$ & $23.7 \pm 1.46^{*} \neq$ & 55.9 & $28.8 \pm 1.56^{*}$ & 84.6 & $26.1 \pm 1.92^{*} \neq$ & 69.4 \\
\hline 12 & $14.3 \pm 0.90$ & $22.8 \pm 1.51^{*} \neq$ & 50 & $24.5 \pm 1.50^{*} \neq$ & 57 & $25.5 \pm 1.78^{*} \neq$ & 65.5 \\
\hline 13 & $14.6 \pm 1.22$ & $25.7 \pm 2.01^{*}$ & 69 & $29.6 \pm 2.34^{*}$ & 89.7 & $30.4 \pm 1.64^{*} \neq$ & 79.4 \\
\hline 16 & $14.0 \pm 1.24$ & $20.9 \pm 1.28^{*} \neq$ & 37.2 & $23.5 \pm 0.94^{*} \neq$ & 50.6 & $22.3 \pm 1.79^{*} \neq$ & 44.8 \\
\hline Tramadol & $13.6 \pm 0.73$ & $29.6 \pm 1.00$ * & 94.7 & $31.6 \pm 0.94$ * & 102.5 & $38.3 \pm 1.47^{*}$ & 148.7 \\
\hline
\end{tabular}

${ }^{*} \mathrm{P}<0.05$ : Statistically significantly from control (Dunnett's test).

$\ddagger \mathrm{P}<0.05$ : Statistically significant from tramadol (Dunnett's test).

Table 1: Central analgesic activity of compounds $(4,5,6,7,8,10,11,12,13$ and 16) in mice. Central pain was induced in Albino mice by thermal stimulation as detailed in the Materials and Methods section. Animals were treated with the test and control compounds and the analgesic activity was determined after 30,60 and 90 min and compared to the controls. Data are shown as mean \pm SEM.

their maximal analgesic effect after $60 \mathrm{~min}(68.5 \%, 77.5 \%, 84.6 \%$ and $89.7 \%$, respectively), then the activity of compounds 11 and 13 started to decrease. Compounds (5 and 13) revealed the most prominent analgesic effect after $30 \mathrm{~min}(67.7 \%$ and $69.0 \%)$.

The analgesic activity of the tested compounds after $90 \mathrm{~min}$, as compared to the reference drug tramadol, arranged in descending order, were $105.8,83.7,80.5,79.4,69.4,69.4,68.8,65.5,44.8$ and $37.0 \%$ in $5,6,4,13,8,11,10,12,16$ and 7 , respectively.

b. Peripheral analgesic activity (Writhing test): The selected compounds showed significant reduction in the number of writhes (Table 2). The most active compounds (4, 6, 7, 8, 10, 12 and 13) showed significant analgesic activity $(85.3,89.1,90.3,80.0,76.5,89.7$ and $83.8 \%)$ which was greater than that of the reference drug aspirin (71.5\%).

Anti-Inflammatory Activity: The selected compounds were evaluated for their possible anti-inflammatory activities in a rat model of carrageenan- induced paw edema. Table 3 shows the effect of selected compounds $(4,5,6,7,8,10,11,12,13$ and 16) on carrageenan-induced paw edema in rats in comparison to indomethacin, as a reference drug. Intra-plantar injection of carrageenan in rats led to increase in paw volume denoting edema in the control non-treated group as shown in Table 3. It was noticed that compounds $(6,8,10,11,12$ and16) in oral doses of $20 \mathrm{mg} / \mathrm{kg}$ significantly decreased the paw edema rate all over the four hours in comparison to the control non-treated group. The anti-inflammatory potencies of selected compounds were calculated by comparing their inhibition rate at different time intervals; with those obtained from animals receiving indomethacin, as standard anti-inflammatory drug. Administration of indomethacin significantly decreased the carrageenin-induced edema starting from the first hour and was persistent till the end of the experiment. The inhibitory effect of indomethacin on paw edema was $32.78,26.35,29.02$, and $27.45 \%$ at the $1^{\text {st }}, 2^{\text {nd }}, 3^{\text {rd }}$ and $4^{\text {th }}$ hour, respectively. It was noticeable that compound 13 failed to decrease inflammation all over the experimental period. Moreover, the compounds ( 7 and 5) failed to decrease inflammation at the $1^{\text {st }}$ hour, while compound 4 failed to decrease inflammation at the $1^{\text {st }}$ and $2^{\text {nd }}$ hours. It is noteworthy to mention that the derivatives 10,12 , and 16 showed anti-inflammatory potency after 4 hours greater than that of indomethacin and reached the maximum effect at the $2^{\text {nd }} h$.

Molecular docking: In an attempt to understand both the antiinflammatory and analgesic data on a structural basis, molecular docking studies were carried out using Mol soft ICM 3.8 software. The aim of the flexible docking calculations is prediction of correct binding geometry for each binder. The scoring functions and hydrogen bonds formed with the surrounding amino acids of the receptor. The new compounds which scores the highest anti-inflammatory activates 10 , 12 and 16 were docked against the active site of COX-1 and COX-2 enzymes. Indomethacin was also docked against both COX-1 and COX-2 and used as reference drug. The scoring functions of the compounds were calculated from minimized ligand protein complexes. The docking results revealed that all the tested compounds showed 


\begin{tabular}{|c|c|c|}
\hline Group & No. of writhes $\mathbf{2 0}$ min. & Protection (\%) \\
\hline Control & $68.0 \pm 2.51 \neq$ & $-{ }^{*}$ \\
\hline $\mathbf{4}$ & $10.0 \pm 0.71^{*} \neq$ & 85.3 \\
\hline $\mathbf{5}$ & $28.0 \pm 2.45^{*} \neq$ & 58.8 \\
\hline $\mathbf{6}$ & $7.4 \pm 0.51^{*} \neq$ & 89.1 \\
\hline $\mathbf{8}$ & $6.6 \pm 0.68^{*} \neq$ & 90.3 \\
\hline $\mathbf{1 0}$ & $13.6 \pm 0.93^{*} \neq$ & 80 \\
\hline $\mathbf{1 1}$ & $16.0 \pm 1.22^{*}$ & 76.5 \\
\hline $\mathbf{1 2}$ & $22.8 \pm 1.98^{*}$ & 66.5 \\
\hline $\mathbf{1 3}$ & $7.0 \pm 0.71^{*} \neq$ & 89.7 \\
\hline Acetylsalicylic acid & $11.0 \pm 1.00^{*} \neq$ & 83.8 \\
\hline
\end{tabular}

${ }^{*} \mathrm{P}<0.05$ : Statistically significantly from control (Dunnett's test).

$\neq \mathrm{P}<0.05$ : Statistically significant from acetyl salicylic acid (Dunnett's test).

Table 2: Peripheral analgesic activity of compounds $(4,5,6,7,8,10,11,12,13$ and 16) in mice. Peripheral pain was induced in Albino mice by acetic acid as detailed in the Materials and Methods section. Animals were treated with the test and control compounds and the analgesic activity was determined after 30,60 and 90 min and compared to the controls. Data are shown as mean \pm SEM.

\begin{tabular}{|c|c|c|c|c|c|c|c|c|}
\hline \multirow{2}{*}{ Group } & \multicolumn{2}{|c|}{$\mathbf{1}$ hour } & \multicolumn{2}{|c|}{$\mathbf{2}$ hours } & \multicolumn{2}{|c|}{$\mathbf{3}$ hours } & \multicolumn{2}{|c|}{$\mathbf{4}$ hours } \\
\cline { 2 - 9 } & Edema rate (\%) & Potency (\%) & Edema rate (\%) & Potency (\%) & Edema rate (\%) & Potency (\%) & Edema rate (\%) & Potency (\%) \\
\hline Control & $42.6 \pm 2.55^{\mathrm{b}}$ & --- & $60.7 \pm 4.98$ & --- & $70.9 \pm 6.49 \mathrm{~b}$ & --- & $72.2 \pm 5.89^{\mathrm{b}}$ & ---- \\
\hline $\mathbf{4}$ & $43.0 \pm 4.15 \mathrm{~b}(0.97)$ & -2.9 & $56.8 \pm 5.22(6.45)$ & -24.5 & $54.6 \pm 4.62(-23.05)$ & 79.4 & $53.2 \pm 4.96 \mathrm{a}(-26.29)$ & 95.8 \\
\hline $\mathbf{5}$ & $43.1 \pm 2.74 \mathrm{~b}(1.23)$ & -3.8 & $50.2 \pm 1.96(-17.26)$ & 65.5 & $61.9 \pm 3.30(-12.77)$ & 44 & $58.3 \pm 3.92(-19.37)$ & 70.6 \\
\hline $\mathbf{6}$ & $38.5 \pm 2.94(-9.55)$ & 29.1 & $55.2 \pm 3.30(-9.03)$ & 34.3 & $59.1 \pm 5.67(-16.63)$ & 57.3 & $57.9 \pm 5.71(-19.90)$ & 72.5 \\
\hline $\mathbf{7}$ & $46.2 \pm 4.53 \mathrm{~b}(8.46)$ & -25.8 & $59.1 \pm 5.88(-2.60)$ & 9.9 & $61.6 \pm 5.04(-13.07)$ & 45 & $64.8 \pm 2.38(-10.30)$ & 37.5 \\
\hline $\mathbf{8}$ & $38.5 \pm 3.80(-9.75)$ & 29.7 & $48.5 \pm 4.12(-20.00)$ & 75.9 & $52.5 \pm 4.77 \mathrm{a}(-26.03)$ & 89.7 & $58.7 \pm 3.60(-18.77)$ & 68.4 \\
\hline $\mathbf{1 0}$ & $26.0 \pm 2.32 \mathrm{a}(-39.09)$ & 119.3 & $32.6 \pm 2.85 \mathrm{a}(-46.29)$ & 175.7 & $43.5 \pm 3.82 \mathrm{a}(-38.73)$ & 133.5 & $47.7 \pm 3.90^{\mathrm{a}}(-34.01)$ & 123.9 \\
\hline $\mathbf{1 1}$ & $33.0 \pm 2.53(-22.54)$ & 68.8 & $36.9 \pm 2.43 \mathrm{a}(-39.19)$ & 148.7 & $52.3 \pm 4.85 \mathrm{a}(-26.24)$ & 90.4 & $53.8 \pm 1.97^{\mathrm{a}}(-25.48)$ & 92.8 \\
\hline $\mathbf{1 2}$ & $28.1 \pm 2.39 \mathrm{a}(-34.14)$ & 104.2 & $42.1 \pm 4.15 \mathrm{a}(-30.64)$ & 116.3 & $51.2 \pm 4.16^{\mathrm{a}}(-27.84)$ & 95.9 & $51.5 \pm 4.09^{\mathrm{a}}(-28.68)$ & 104.5 \\
\hline $\mathbf{1 3}$ & $48.8 \pm 4.03 \mathrm{~b}(14.64)$ & -44.7 & $65.5 \pm 4.20 \mathrm{~b}(7.94)$ & -30.1 & $74.5 \pm 2.25 \mathrm{~b}(5.1)$ & -17.6 & $74.9 \pm 4.00 \mathrm{~b}(3.65)$ & -13.3 \\
\hline $\mathbf{1 6}$ & $29.3 \pm 2.11 \mathrm{a}(-31.14)$ & 94.9 & $41.8 \pm 2.82 \mathrm{a}(-31.16)$ & 118.3 & $48.1 \pm 2.37^{\mathrm{a}}(-32.15)$ & 110.8 & $49.3 \pm 2.32^{\mathrm{a}}(-31.71)$ & 115.5 \\
\hline $\begin{array}{c}\text { Indometha- } \\
\text { cin }\end{array}$ & $28.6 \pm 2.39 \mathrm{a}(-32.78)$ & 100 & $44.7 \pm 3.84(-26.35)$ & 100 & $50.3 \pm 3.60 \mathrm{a}(-29.02)$ & 100 & $52.4 \pm 4.34^{\mathrm{a}}(-27.45)$ & 100 \\
\hline
\end{tabular}

Each value in parenthesis indicates the percentage inhibition rate, ${ }^{a} \mathrm{P}<0.05$ : Statistically significantly from control (Dunnett's test). ${ }^{\mathrm{b}} \mathrm{P}<0.05$ : Statistically significant from indomethacin (Dunnett's test). The potency was calculated comparing to the reference drug indomethacin.

Table 3: Anti-inflammatory activity of compounds $(4,5,6,7,8,10,11,12,13$ and 16) against carrageenan-induced paw edema in rats. Carrageenan-induced Paw edema was induced in Wistar rats as described in the subjects and Methods section. Animals were treated with the test and control compounds and the anti-inflammatory activity was determined after 1, 2, 3 and 4 hours and compared to the controls. Data are shown as mean \pm SEM.

non-selective inhibition of both COX-1 and COX-2 enzymes. Results of their interaction energies with COX-1 and COX-2 are shown in Table 4.

The docking results revealed that all tested compounds 10,12 and 16 bound nicely to the active site of both cyclooxygenase enzymes I and II, scoring bonding energies ranging from -26.89 to $-46.21 \mathrm{Kcal} / \mathrm{mol}$ for COX-I, and -30.96 to $-43.44 \mathrm{Kcal} / \mathrm{mol}$ for COX-II. Compared to -14.76 and $-26.36 \mathrm{Kcal} / \mathrm{mol}$ for indomethacin reference drug for both COX-I and COX-II respectively, details of the interactions and $\mathrm{H}$-bonding between tested compounds and COX enzymes are listed in (Figures $2 \mathrm{a}-2 \mathrm{~d}$ and $3 \mathrm{a}-3 \mathrm{~d})$. The ICM score values show good agreement with predicted binding affinities obtained by molecular docking studies as verified by pharmacological screening.

\section{Conclusion}

In this work, we have prepared a series of new pyrazolone derivatives in combination with pyrazole and dihydropyrimidinone scaffold, as well as heteroaryl and aryl pyrazole derivatives. The analgesic and anti-inflammatory activities were investigated for the title compounds utilizing the acetic acid-induced writhing test and the carrageenaninduced hind paw edema test, respectively.

The newly synthesized pyrazolone derivatives were found to possess potent analgesic and anti-inflammatory activities. The results showed that the central analgesic potencies of the tested compounds

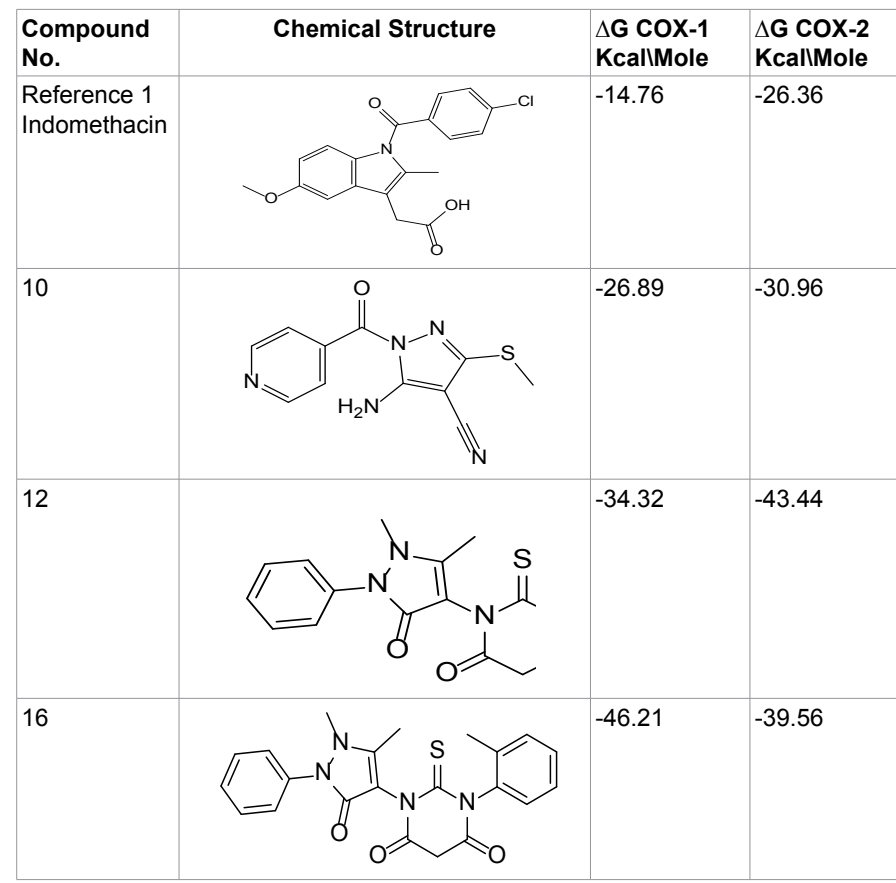

Table 4: Interaction energies of compounds Indomethacin, 10,12 and 16 with the COX-1 and COX-2 enzymes. 


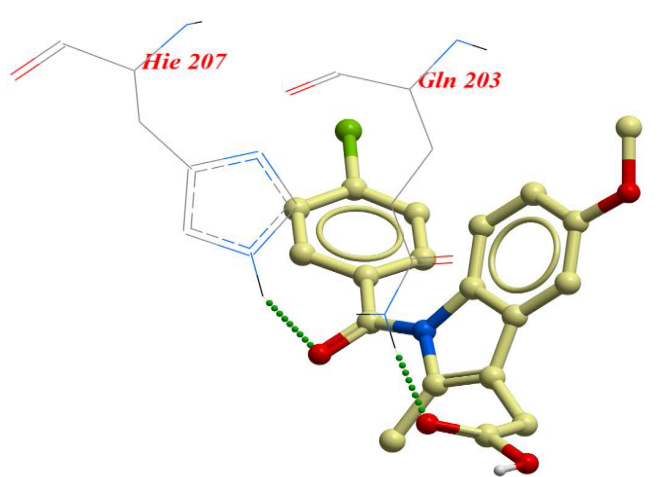

Figure 2a: Binding mode of the original ligand indomethacin into binding site of COX-l, showing two H-bonds between $\mathrm{H} 21$ of $\mathrm{Gln} 203$ with $\mathrm{CO}$ of the Carboxyl group of Indomethacin and $\mathrm{H} 2$ of Hie204 with $\mathrm{O}$ of the Carbonyl group of Indomethacin.

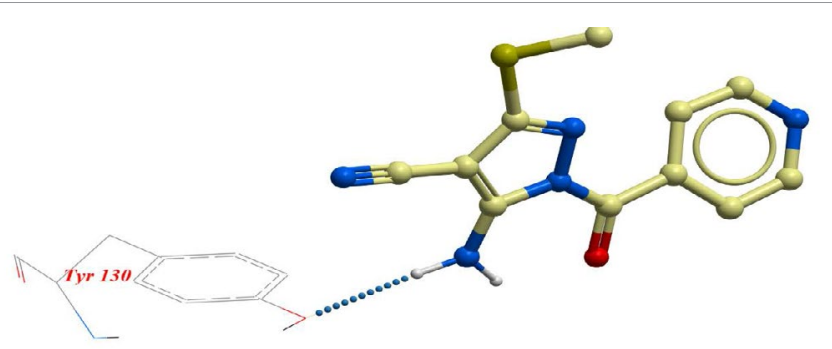

Figure 2b: Binding mode of compound 10 into binding site of COX-I, showing one $\mathrm{H}$-bond between $\mathrm{OH}$ of Tyr130 with $\mathrm{NH}$ of the amino group in compound 10.

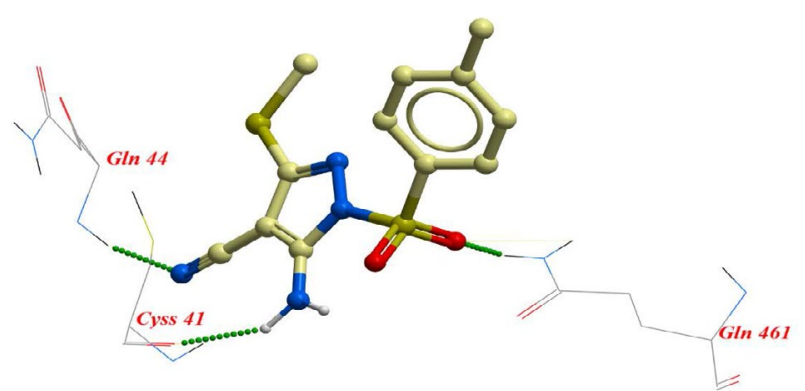

Figure 2c: Binding mode of compound 12 into binding site of COX-I, showing two $\mathrm{H}$-bonds between $\mathrm{NH} 2$ of amide group in $\mathrm{Gln} 461$ with $\mathrm{O}$ of the sulfoxide group in 12 and one $\mathrm{H}$-bond between $\mathrm{O}$ of the carboxyl group in Cys 41 with $\mathrm{NH}$ of the amino group in 12. In addition to one $\mathrm{H}$-bond between $\mathrm{NH}$ of the amino group in $\mathrm{Gln} 44$ with $\mathrm{N}$ of the $\mathrm{CN}$ group in 12.

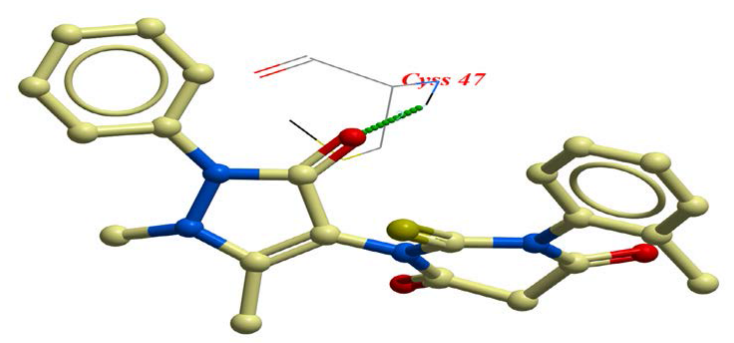

Figure 2d: Binding mode of compound 16 into binding site of COX-I, Showing one $\mathrm{H}$-bond between $\mathrm{NH}$ of the amino group in Cys47 with $\mathrm{O}$ of the carbonyl group in the pyrzole ring in 16.

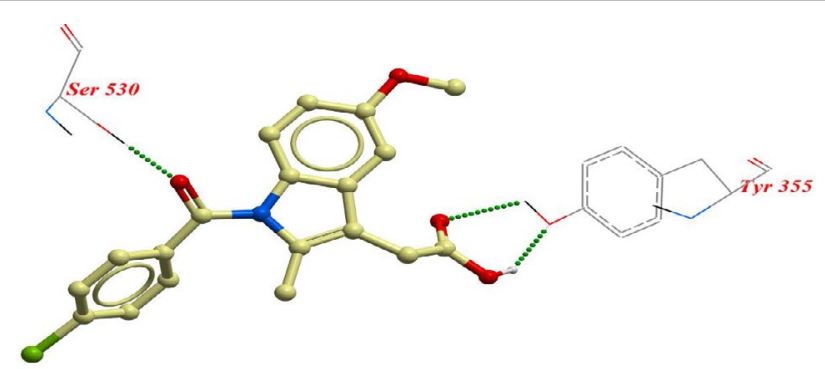

Figure 3a: Binding mode of the original ligand indomethacin into binding site of COX-II, showing $\mathrm{H}$-bond between $\mathrm{H}$ of $\mathrm{OH}$ in Ser530 with $\mathrm{O}$ of the carbonyl group in Indomethacin. In addition to two $\mathrm{H}$-bonds between $\mathrm{H}$ of the phenolic $\mathrm{OH}$ in Tyr355 with $\mathrm{CO}$ of the carboxyl group in Indomethacin and $\mathrm{O}$ of the phenolic $\mathrm{OH}$ in Tyr355 with $\mathrm{H}$ of the carboxyl group in Indomethacin.

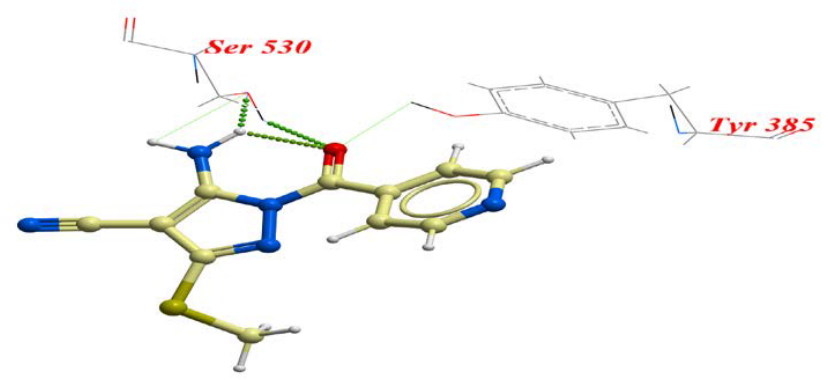

Figure 3b: Binding mode of compound 10 into binding site of COX-II, Showing three $\mathrm{H}$-bonds between Ser530 with $\mathrm{NH} 2$ and $\mathrm{O}$ of the carbonyl group in 10. In addition to a fourth $\mathrm{H}$-bond between $\mathrm{H}$ of the phenolic $\mathrm{OH}$ in Tyr385 with $\mathrm{O}$ of the carbonyl group in $\mathbf{1 0 .}$

1

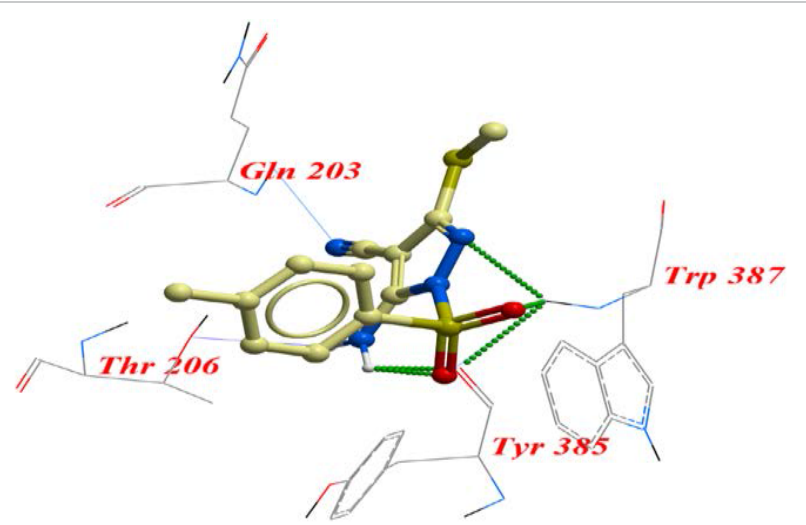

Figure 3c: Binding mode of compound 12 into binding site of COX-II, showing six $\mathrm{H}$-bonds between $\mathrm{GIn} 203$ with N of CN, Trp387 with O1, O2 and N2 in 12, $\mathrm{H}$-bond between $\mathrm{Thr} 206$ with $\mathrm{H} 5$ in 12. In addition to a $\mathrm{H}$-bond between Tyr385 with $\mathrm{H} 6$ of compound 12.

after $90 \mathrm{~min}$, as compared to tramadol, arranged in descending order, were $105.8,83.7,80.5,79.4,69.4,69.4,68.8,65.5,44.8$ and $37.0 \%$ in 5 , $6,4,13,8,11,10,12,16$ and 7 , respectively. In the acetic acid induced writhing test the selected Compounds showed significant reduction in the number of writhes. The compounds $(4,6,7,8,10,12$ and 13) showed analgesic activity in a percent $\%(85.3,89.1,90.3,80.0,76.5$, 89.7 and 83.8) which was greater than that of acetyl salicylic acid (71.5\%). The selected Compounds were evaluated for their possible anti-inflammatory effects in a rat model of carrageenan- induced paw edema. It was noticed that compounds, $(6,8,10,11,12$, and16) in oral doses of $20 \mathrm{mg} / \mathrm{kg}$ significantly decreased the paw edema rate all over 


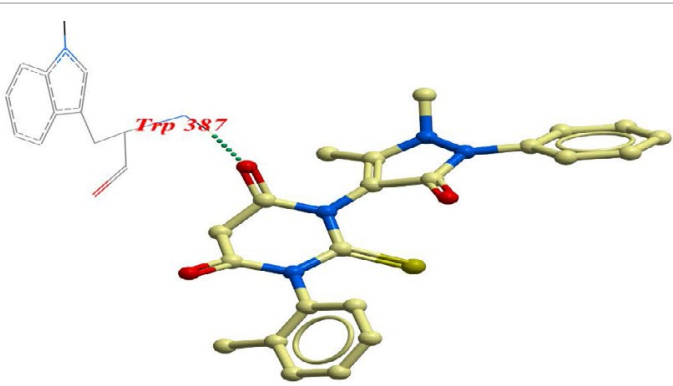

Figure 3d: Binding mode of compound 16 into binding site of COX-II, showing one $\mathrm{H}$-bond between $\mathrm{H}$ of the $\mathrm{NH} 2$ in Trp387 with $\mathrm{O} 2$ of the carbonyl group in 16.

the four hours in comparison to the control non-treated group. It is noteworthy to mention that the derivatives 10,12 and 16 showed antiinflammatory potency after 4 hours greater than that of indomethacin and reached the maximum effect at the $2^{\text {nd }} \mathrm{h}$.

\section{References}

1. Ferreira SH, Moncada S, Vane JR (1971) Indomethacin and aspirin abolish prostaglandin release from the spleen. Nat New Biol 231: 237-239.

2. Dannhardt G, Kiefer W (2001) Cyclooxygenase inhibitors--current status and future prospects. Eur J Med Chem 36: 109-126.

3. Carter JS (2000) Inhibitors of cyclooxygenase-2: November 1999-April 2000. Expert Opinion on Therapeutic Patents 10: 1011-1020.

4. Talley JJ (1999) Selective inhibitors of cyclooxygenase-2 (COX-2). Prog Med Chem 36: 201-234.

5. Skoutakis VA, Carter CA, Mickle TR, Smith VH, Arkin CR, et al. (1988) Review of diclofenac and evaluation of its place in therapy as a nonsteroidal antiinflammatory agent. Drug Intell Clin Pharm 22: 850-859

6. Lombardino JG (1985) Nonsteroidal antiinflammatory drugs. Wiley-Interscience.

7. Kujubu DA, Fletcher BS, Varnum BC, Lim RW, Herschman HR (1991) TIS10, a phorbol ester tumor promoter-inducible mRNA from Swiss 3T3 cells, encodes a novel prostaglandin synthase/cyclooxygenase homologue. J Biol Chem 266 12866-12872.

8. Chan C-C, Boyce S, Brideau C, Charleson S, Cromlish W, et al. (1999) Rofecoxib [Vioxx, MK-0966; 4-(4'-methylsulfonylphenyl)-3-phenyl-2-(5H)-furanone]: a potent and orally active cyclooxygenase-2 inhibitor. Pharmacological and biochemical profiles. Journal of Pharmacology and Experimental Therapeutics 290: 551-560.

9. Palomer A, Cabre F, Pascual J, Campos J, Trujillo MA, et al. (2002) Identification of novel cyclooxygenase-2 selective inhibitors using pharmacophore models. J Med Chem 45: 1402-1411.

10. Fioravanti R, Bolasco A, Manna F, Rossi F, Orallo F, et al. (2010) Synthesis and biological evaluation of $\mathrm{N}$-substituted-3,5-diphenyl-2-pyrazoline derivatives as cyclooxygenase (COX-2) inhibitors. Eur J Med Chem 45: 6135-6138.

11. Khalil NA, Ahmed EM, El-Nassan HB, Ahmed OK, Al-Abd AM (2012) Synthesis and biological evaluation of novel pyrazoline derivatives as anti-inflammatory and antioxidant agents. Arch Pharm Res 35: 995-1002.

12. Bandgar BP, Adsul LK, Chavan HV, Jalde SS, Shringare SN, et al. (2012) Synthesis, biological evaluation, and docking studies of 3(substituted)-aryl-5-(9-methyl-3-carbazole)-1H-2-pyrazolines as potent antiinflammatory and antioxidant agents. Bioorganic \& medicinal chemistry letters 22: $5839-5844$

13. Jadhav SY, Shirame SP, Kulkarni SD, Patil SB, Pasale SK, et al. (2013) PEG mediated synthesis and pharmacological evaluation of some fluoro substituted pyrazoline derivatives as antiinflammatory and analgesic agents. Bioorganic \& medicinal chemistry letters 23: 2575-2578

14. Patel MV, Bell R, Majest S, Henry R, Kolasa T (2004) Synthesis of 4,5diaryl-1H-pyrazole-3-ol derivatives as potential COX-2 inhibitors. J Org Chem 69: 7058-7065.

15. Maggio B, Daidone G, Raffa D, Plescia S, Mantione L, et al. (2001) Synthesis and pharmacological study of ethyl 1-methyl-5-(substituted 3,4-dihydro-4oxoquinazolin-3-yl)-1H-pyrazole-4-acetates. Eur J Med Chem 36: 737-742.

16. Abdel-Aziz HA, Al-Rashood KA, ElTahir KEH, Suddek GM (2014) Synthesis of $\mathrm{N}$-benzenesulfonamide- $1 \mathrm{H}$-pyrazoles bearing arylsulfonyl moiety: Novel celecoxib analogs as potent anti-inflammatory agents. European journal of medicinal chemistry 80: 416-422.

17. Khalil NA, Ahmed EM, Mohamed KO, Nissan YM, Zaitone SA (2014) Synthesis and biological evaluation of new pyrazolone-pyridazine conjugates as antiinflammatory and analgesic agents. Bioorg Med Chem 22: 2080-2089.

18. Kumar A, Sharma S, Bajaj K, Bansal D, Sharma D, et al. (2003) Synthesis and anti-inflammatory, analgesic, ulcerogenic, and cyclooxygenase activities of novel quinazolinyl-? 2-pyrazolines. Indian J Chem B 42: 1979-1984.

19. Radzikowska E, Onish K and Chojak E (1995) 1077 Prospective assessment of cancer incidence and antipyrine metabolism. European Journal of Cancer 31: S225.

20. Khanduja KL, Dogra SC, Kaushal S, Sharma RR (1984) The effect of anticancer drugs on pharmacokinetics of antipyrine in vitamin A deficiency. Biochem Pharmacol 33: 449-452.

21. Mahmoud M, Abdel-Kader R, Hassanein M, Saleh S, Botros S (2007) Antipyrine clearance in comparison to conventional liver function tests in hepatitis $C$ virus patients. Eur J Pharmacol 569: 222-227.

22. Evstropov A, Yavorovskaya V, Vorob'ev E, Khudonogova Z, Gritsenko L, et al. (1992) Synthesis and antiviral activity of antipyrine derivatives. Pharmaceutical Chemistry Journal 26: 426-430.

23. Michon V, du Penhoat CH, Tombret F, Gillardin J, Lepage F, et al. (1995) Preparation, structural analysis and anticonvulsant activity of 3 -and 5-aminopyrazole $\mathrm{N}$-benzoyl derivatives. European journal of medicinal chemistry 30: 147-155.

24. Ispir E, Toroglu S and Kayraldiz A (2008) Syntheses, characterization, antimicrobial and genotoxic activities of new Schiff bases and their complexes. Transition metal chemistry 33: 953-960.

25. Comber RN, Gray RJ, Secrist JA 3rd (1991) Acyclic analogues of pyrazofurin: syntheses and antiviral evaluation. Carbohydr Res 216: 441-452.

26. El-Nezhawy AO, Gaballah ST, Radwan MA, Baiuomy AR, Abdel-Salam OM (2009) Structure-based design of benzimidazole sugar conjugates: synthesis, SAR and in vivo anti-inflammatory and analgesic activities. Med Chem 5: 558-569.

27. Eweas AF, El-Nezhawy AO, Baiuomy AR and Awad MM (2013) Design synthesis, anti-inflammatory, analgesic screening, and molecular docking of some novel 2-pyridyl (3H)-quinazolin-4-one derivatives. Medicinal Chemistry Research 22: 1011-1020.

28. El-Nezhawy AO, Biuomy AR, Hassan FS, Ismaiel AK, Omar HA (2013) Design synthesis and pharmacological evaluation of omeprazole-like agents with antiinflammatory activity. Bioorg Med Chem 21: 1661-1670.

29. Turner RA (2013) Screening methods in pharmacology. Elsevier.

30. Collier HO, Dinneen LC, Johnson CA, Schneider C (1968) The abdominal constriction response and its suppression by analgesic drugs in the mouse. $\mathrm{Br}$ J Pharmacol Chemother 32: 295-310.

31. Winter CA, Risley EA, Nuss GW (1962) Carrageenin-induced edema in hind paw of the rat as an assay for antiiflammatory drugs. Proc Soc Exp Biol Med 111: 544-547.

32. Fathalla OA, Zaki ME, Swelam SA, Nofal SM, el-Eraky WI (2003) Facile synthesis of fused pyrazolo[1,5-a]pyrimidinepyrazolo [1,5-a]triazines and $\mathrm{N}$-sulphonamidopyrazoles as antiinflammatory. Acta Pol Pharm 60: 51-60. 